\title{
Glutathione Depletion Impairs Transcriptional Activation of Heat Shock Genes in Primary Cultures of Guinea Pig Gastric Mucosal Cells
}

\author{
Kazuhito Rokutan, Tetsuya Hirakawa, Shigetada Teshima, Soichi Honda, and Kyoichi Kishi \\ Department of Nutrition, School of Medicine, The University of Tokushima, Tokushima 770, Japan
}

\begin{abstract}
When primary cultures of guinea pig gastric mucosal cells were exposed to heat $\left(43^{\circ} \mathrm{C}\right)$, ethanol, hydrogen peroxide $\left(\mathrm{H}_{2} \mathrm{O}_{2}\right)$, or diamide, heat shock proteins (HSP90, HSP70, HSP60, and HSC73) were rapidly synthesized. The extent of each HSP induction varied with the type of stress. Ethanol, $\mathrm{H}_{2} \mathrm{O}_{2}$, and diamide increased the syntheses of several other undefined proteins besides the HSPs. However, none of these proteins were induced by exposure to heat or the reagents, when intracellular glutathione was depleted to $<10 \%$ of the control level by pretreatment with DL-buthionine[S,R]-sulfoximine. Gel mobility shift assay using a synthetic oligonucleotide coding HSP70 heat shock element showed that glutathione depletion inhibited the heat- and the reagent-initiated activation of the heat shock factor 1 (HSF1) and did not promote the expression of HSP70 mRNA. Immunoblot analysis with antiserum against HSF1 demonstrated that the steady-state level of HSF1 was not changed in glutathione-depleted cells, but glutathione depletion inhibited the nuclear translocation of HSF1 after exposure to heat stress. These results suggest that intracellular glutathione may support early and important biochemical events in the acquisition by gastric mucosal cells of an adaptive response to irritants. (J. Clin. Invest. 1996. 97:22422250.) Key words: stress response • adaptive cytoprotection - glutathione redox $\bullet$ heat shock protein $\bullet$ heat shock factor 1
\end{abstract}

\section{Introduction}

The increase in the resistance of gastric mucosa to various necrotizing agents that occurs after treatment with mild irritants is named "adaptive cytoprotection" (1). Endogenous vasoactive mediators, including prostanoids, nitric oxide, and sensory neuropeptides, have been suggested to participate in this adaptation by regulating gastric blood flow and mucosal integrity (for review see reference 2). Gastric epithelium is frequently exposed to hot food, ethanol, and oxidants generated from ingested food, catalase-negative bacteria, and cigarette smoke (3-6). Gastric mucous epithelial cells are the first line of defense against these irritants. Interest has recently been focused on the molecular mechanism by which gastric mucosal cells de-

Address correspondence to Kazuhito Rokutan, M.D., Department of Nutrition, School of Medicine, The University of Tokushima, 3-18-15 Kuramoto-cho, Tokushima 770, Japan. Phone: 886-31-3111 ext. 2506; FAX: 886-33-7086.

Received for publication 17 April 1995 and accepted in revised form 23 February 1996.

J. Clin. Invest.

(C) The American Society for Clinical Investigation, Inc.

0021-9738/96/05/2242/09 \$2.00

Volume 97, Number 10, May 1996, 2242-2250 fend themselves against irritant-induced injury. We previously reported that primary cultures of gastric mucosal cells respond to heat stress by rapid induction of a set of highly conserved proteins, termed heat shock protein (HSP), ${ }^{1}$ and we suggested that these HSPs may play an important role in protection against cell damage caused by subsequent exposure to high concentrations of ethanol (7). The stress response in mammalian cells is suggested to occur via transcriptional induction of heat shock genes mediated by activation of a pre-existing pool of the heat shock transcription factor (HSF), which binds to the heat shock promoter element (HSE) (see references 8 and 9 for reviews).

Glutathione, a ubiquitous thiol, is involved in many cellular functions $(10,11)$ and has been postulated to mediate gastric mucosal protection (12). However, there is some controversy about the relationship between the endogenous glutathione level and acquisition of adaptive cytoprotection in vivo (13, 14). Glutathione has been shown to protect cultured gastric cells against oxygen radicals (15) and acid (16), and we have suggested that it may prevent irreversible reorganization of microfilaments of gastric epithelial cells under oxidative stress, possibly through S-thiolation of actin (17). In addition, glutathione has been suggested to mediate the initial response for acquiring tolerance to heat stress (18).

The present study was designed to determine whether glutathione regulates the acquisition of endogenous defense through induction of HSPs. When the intracellular glutathione level of cultured gastric mucosal cells was depleted to $<10 \%$ of that of control cells by treatment with a specific inhibitor of glutamylcysteine synthetase, buthionine-[S,R]-sulfoximine (BSO), the induction of HSPs did not occur after exposure to heat, ethanol, hydrogen peroxide $\left(\mathrm{H}_{2} \mathrm{O}_{2}\right)$, or diamide. Here we provide evidence that depletion of glutathione may impair transcriptional activation of heat shock genes in cultured gastric mucosal cells.

\section{Methods}

Reagents and media. RPMI 1640, Hanks' balanced salt solution without phenol red (HBSS), and Eagle's minimum essential medium (MEM) were purchased from Nissui Pharmaceutical Co., Tokyo. Methionine-free RPMI 1640 was from GIBCO BRL (Gaithersburg, MD). Fetal calf serum (FCS) was obtained from Flow General Co. (McLean, VA). ${ }^{35}$ S-Protein labeling mix containing $\geq 77 \%$ L-methionine and $\geq 18 \%$ L-cysteine $(>1000 \mathrm{Ci} / \mathrm{mmol})$ was from DuPont/ New England Nuclear (Boston, MA). Rabbit polyclonal antibodies against HSP90 (19), HSP70 with a molecular mass of $72 \mathrm{kD}(20)$, HSP60 (21), and a cognate 73-kD HSP (HSC73) (20) were gifts from Dr. Hideaki Itoh, Akita University. Rabbit antiserum against rat

1. Abbreviations used in this paper: HSP, heat shock protein; HSF, heat shock factor; HSE, heat shock promoter element; BSO, buthionine-[S,R]-sulfoximine; GAPDH, glyceraldehyde 3-phosphate dehydrogenase; PVDF, polyvinylidene difluoride. 
HSF1 was a gift from Dr. Kazuhiro Nagata, Kyoto University. cDNA clones for human HSP70 (ATCC 57494) and glyceraldehyde-3-phosphate dehydrogenase (GAPDH, ATCC 57090) were purchased from American Type Culture Collection (Rockville, MD). Milk casein (Block $\left.\mathrm{ace}^{\mathrm{TM}}\right)$ was from Yukijirushi (Sapporo, Japan). $\left[\gamma^{-32} \mathrm{P}\right]$ ATP $(>5,000$ $\mathrm{Ci} / \mathrm{mmol}),\left[\alpha^{-32} \mathrm{P}\right] \mathrm{CTP}(>3,000 \mathrm{Ci} / \mathrm{mmol}), \mathrm{T} 4$ polynucleotide kinase, a random primer kit, and an enhanced chemiluminescence (ECL) Western blot detection kit were purchased from the Amersham Japan, Tokyo. Poly $(\mathrm{dI}-\mathrm{dC}) \cdot \operatorname{poly}(\mathrm{dI}-\mathrm{dC})$ was from Pharmacia LKB Biotechnology Inc. (Sweden).

Preparation and culture of gastric mucosal cells. Male guinea pigs weighing $\sim 250$ grams were purchased from Japan SLC Inc. (Shizuoka, Japan). Gastric mucosal cells were isolated aseptically from fundic glands and cultured for $2 \mathrm{~d}$ in RPMI 1640 containing $10 \%$ FCS, $2 \mathrm{mM}$ glutamine, $100 \mu \mathrm{g} / \mathrm{ml}$ streptomycin, and $100 \mathrm{U} / \mathrm{ml}$ penicillin, as described previously $(7,17)$. The periodic acid-Schiff reaction showed that $>85 \%$ of the cultured cells were mucus secreting $(7,17)$. Intracellular glutathione was depleted by treating the cells with BSO at various concentrations. Cell protein was measured by the method of Lowry et al. Cell viability was assessed by trypan blue exclusion test and by lactate dehydrogenase (LDH) release, as described previously (7).

Measurement of intracellular glutathione content. The contents of reduced glutathione (GSH) and its disulfide (GSSG) in cultured cells were measured as described previously (17). Briefly, acid-soluble thiols were extracted by treating the cells in $35-\mathrm{mm}$-diameter culture dishes with $200 \mu \mathrm{l}$ of $5 \%$ perchloric acid containing $2.5 \mathrm{mM} o$-phenanthroline for $30 \mathrm{~min}$ on ice. The supernatants, obtained by centrifugation at $11,300 \mathrm{~g}$ for $20 \mathrm{~min}$, were made alkaline by addition of excess $\mathrm{NaHCO}_{3}$ and subsequently alkylated with iodoacetic acid. The mixtures were then treated with 3\% 1-fluoro-2,4-dinitrobenzene overnight at $4^{\circ} \mathrm{C}$, and the fluorodinitrophenyl derivatives were subjected to HPLC analysis (22).

Exposure of cells to heat or chemicals. Cells growing in $35-\mathrm{mm}-$ diameter culture dishes (Becton Dickinson Japan, Tokyo) were washed twice with phosphate-buffered saline (PBS) and incubated for $20 \mathrm{~min}$ with MEM at $37^{\circ} \mathrm{C}$. The MEM was adjusted to $\mathrm{pH} 7.4$ with $1 \mathrm{~N}$ $\mathrm{NaOH}$ before use. The medium was immediately replaced by MEM prewarmed at $43^{\circ} \mathrm{C}$, and the dishes were placed in a water bath at $43^{\circ} \mathrm{C}$ for the indicated times. Alternatively, cells preincubated with MEM at $37^{\circ} \mathrm{C}$ were exposed to various concentrations of hydrogen peroxide $\left(\mathrm{H}_{2} \mathrm{O}_{2}\right)$, ethanol, or diamide, for the indicated times.

Protein labeling and analysis of synthesized proteins. Immediately after exposure to heat or chemicals, the cells were washed twice with PBS prewarmed at $37^{\circ} \mathrm{C}$ and incubated for $1 \mathrm{~h}$ in methionine-free RPMI 1640 containing $10 \%$ dialyzed FCS and $50 \mu \mathrm{M} \mathrm{L}-\left[{ }^{35}\right.$ S $]$ methionine $(16 \mu \mathrm{Ci} / \mathrm{ml})$. After labeling, the medium was removed, and the cells were washed twice with PBS. Then, $100 \mu l$ of sample buffer containing $50 \mathrm{mM}$ Tris- $\mathrm{HCl}$ (pH 6.8), $2 \%$ sodium dodecyl sulfate (SDS), $10 \%$ glycerol, $2 \%$ 2-mercaptoethanol, and $0.001 \%$ bromophenol blue for SDS-PAGE was added to the plates. The cell lysate was collected with a rubber policeman and transferred to a microcentrifuge tube. The lysate was passed through a 27-gauge needle several times and boiled for $2 \mathrm{~min}$. The extracted proteins were subjected to SDSPAGE in $10 \%$ polyacrylamide gel. The gel was stained with Coomassie brilliant blue R-250, dried, and exposed to Fuji RX-R film (Fuji Photo Film, Tokyo) for autoradiography.

Preparation of whole-cell, cytosol, and nuclear extracts. Whole-cell extracts for gel mobility shift assay were prepared based on the method of Mosser et al. (23). Confluent cells in $60-\mathrm{mm}$-diameter culture dishes were untreated or treated with $50 \mu \mathrm{M}$ BSO for $18 \mathrm{~h}$ and then exposed to heat at $43^{\circ} \mathrm{C}$, or to chemicals, for the indicated times. The cells were harvested and transferred to microcentrifuge tubes. After centrifugation at $5,000 \mathrm{rpm}$ for $5 \mathrm{~s}$ in a microcentrifuge, pelleted cells were rapidly frozen in liquid nitrogen. The frozen pellets were suspended in $20 \mathrm{mM} N$-2-hydroxyethylpiperazine- $N^{\prime}$-2-ethanesulfonic acid buffer (Hepes, pH 7.9) containing $25 \%$ (vol/vol) glycerol, $0.42 \mathrm{M}$ $\mathrm{NaCl}, 1.5 \mathrm{mM} \mathrm{MgCl}, 0.2 \mathrm{mM}$ EDTA, $0.5 \mathrm{mM}$ phenylmethylsulfonyl fluoride (PMSF), $1 \mu \mathrm{g} / \mathrm{ml}$ leupeptin, and $0.5 \mathrm{mM}$ dithiothreitol
(DTT). The mixture was gently pipetted with a pasteur pipette and was stood on ice for $15 \mathrm{~min}$. Whole-cell extracts were obtained by ultracentrifugation at $100,000 \mathrm{~g}$ for $5 \mathrm{~min}$ at $4^{\circ} \mathrm{C}$. The supernatants were dialyzed against binding reaction buffer, consisting of $10 \mathrm{mM}$ Tris$\mathrm{HCl}$ ( $\mathrm{pH} 7.8$ ), $50 \mathrm{mM} \mathrm{NaCl}, 1 \mathrm{mM}$ EDTA, $0.5 \mathrm{mM}$ DTT, $0.5 \mathrm{mM}$ PMSF, $1 \mu \mathrm{g} / \mathrm{ml}$ leupeptin, and $5 \%$ glycerol, using an oscillatory microdialysis system (Bio-Tech International Inc., Bellenue, WA). The dialyzed supernatants were stored at $-80^{\circ} \mathrm{C}$.

Cytosol and nuclear extracts for immunoblot analysis of HSF1 were prepared by the method of Schreiber et al. (24). The washed cell pellets were suspended in $10 \mathrm{mM}$ Hepes buffer, $\mathrm{pH} 7.9$, containing 10 $\mathrm{mM} \mathrm{KCl}, 0.1 \mathrm{mM}$ EDTA, $0.1 \mathrm{mM}$ EGTA, $0.5 \mathrm{mM}$ DTT, $0.2 \mathrm{mM}$ PMSF, and $1 \mu \mathrm{g} / \mathrm{ml}$ leupeptin. The cells were allowed to swell on ice for $10 \mathrm{~min}$, and then they were lysed by adding Nonidet P-40 at a final concentration of $0.6 \%(\mathrm{vol} / \mathrm{vol})$. Lysis was completed by vortexing for $10 \mathrm{~s}$. The sample was centrifuged at $13,000 \mathrm{~g}$ for $30 \mathrm{~s}$ in a microcentrifuge at $4^{\circ} \mathrm{C}$. The supernatant was used as the cytosolic fraction. The resulting pellet was resuspended in $20 \mathrm{mM}$ Hepes, $\mathrm{pH}$ 7.9, containing $25 \%$ (vol/vol) glycerol, $0.42 \mathrm{M} \mathrm{NaCl}, 1 \mathrm{mM}$ EDTA, $1 \mathrm{mM}$ EGTA, 0.2 $\mathrm{mM}$ PMSF, and $1 \mu \mathrm{g} / \mathrm{ml}$ leupeptin, and agitated on ice for $20 \mathrm{~min}$. The supernatant obtained by centrifugation at $13,000 \mathrm{~g}$ for $20 \mathrm{~min}$ at $4^{\circ} \mathrm{C}$ was used as the nuclear extract.

Immunoblot analysis. For detection of HSPs by immunoblot analysis, cells were lysed with SDS-PAGE sample buffer. The lysate was passed through at 27-gauge needle several times and boiled for 2 min. For detection of HSF1, the cytosol or the nuclear extract, prepared as described above, was subjected to $10 \%$ SDS-PAGE. The separated proteins were transferred to a polyvinylidene difluoride (PVDF) membrane. After blocking nonspecific binding sites with $4 \%$ milk casein, the membrane was incubated with antibody against HSP90, HSC73, HSP70, or HSP60, or antiserum against HSF1, for $1 \mathrm{~h}$ at room temperature. After washing with PBS containing $0.2 \%$ Tween-20, bound antibodies were detected with an ECL detection kit.

Northern blot analysis. Total RNA was isolated with an acid guanidinium thiocyanate-phenol-chloroform mixture (25). Samples of $15 \mu \mathrm{g}$ of total RNA were subjected to electrophoresis in $1 \%$ agarose gels containing $0.6 \mathrm{M}$ formaldehyde and transferred to nylon membrane filters (Hybond ${ }^{\mathrm{TM}}-\mathrm{N}+$, Amersham). The filters were hybridized for $4 \mathrm{~h}$ at $65^{\circ} \mathrm{C}$ with the cDNA probe for human HSP70 or GAPDH, which was labeled with $\left[\alpha{ }^{32} \mathrm{P}\right] \mathrm{CTP}$ to a specific activity of $>10^{8} \mathrm{cpm}$ with a random-primer kit. After hybridization, the filters were washed twice with $2 \times \operatorname{SSC}(0.3 \mathrm{M} \mathrm{NaCl}, 0.03 \mathrm{M}$ sodium citrate $)$ containing $0.5 \%$ SDS for $10 \mathrm{~min}$ at room temperature and then three times with $0.2 \times \mathrm{SSC}$ containing $1 \% \mathrm{SDS}$ for $10 \mathrm{~min}$ at $65^{\circ} \mathrm{C}$. Bound probes were analyzed using a Fujix Bio-Analyzer BAS-2000 (Fuji Photo Film) and autoradiographed by exposure to Fuji RX-R film for an appropriate time.

Gel mobility shift assay. The probe used to detect the DNA binding activity of HSF was synthesized by a DNA synthesizer (Model 392; Applied Biosystem, Foster City, CA). The double-stranded HSE oligonucleotide encoded nucleotides -107 to -83 of the human HSP70 gene (5'-GATCTCGGCTGGAATATTCCCGACCTGGCAGCCGA-3') (23). The [ $\left.{ }^{32} \mathrm{P}\right]$ HSE oligonucleotide was prepared by $5^{\prime}$-end labeling one strand with T4 kinase and $\left[\gamma^{-32} \mathrm{P}\right] \mathrm{ATP}$. The labeled nucleotide was isolated by Sephadex G-50 chromatography. The radiolabeled nucleotide was annealed to the complementary strand. The AP-1 oligonucleotide in the human c-jun promoter $(-77$ TTGGGGTGACATCATGGGCTA -57) was used as a non-self competitor.

For gel mobility shift assay, $7 \mu \mathrm{g}$ of whole-cell extract was mixed with $0.1 \mathrm{ng}$ of $\left[{ }^{32} \mathrm{P}\right] \mathrm{HSE}$ oligonucleotide and $2 \mu \mathrm{g}$ of poly $(\mathrm{dI}-\mathrm{dC}) \cdot$ poly (dI-dC) in binding reaction buffer in a final volume of $20 \mu \mathrm{l}$. The binding reaction was carried out for $20 \mathrm{~min}$ at $25^{\circ} \mathrm{C}$, and $2 \mu \mathrm{l}$ of a dye solution containing $0.2 \%$ bromophenol blue, $0.2 \%$ xylene cyanol, and $50 \%$ glycerol was added. The mixtures were loaded onto $4 \%$ polyacrylamide gel in $6.7 \mathrm{mM}$ Tris ( $\mathrm{pH} 7.5$ ) containing $1 \mathrm{mM}$ EDTA and $3.3 \mathrm{mM}$ sodium acetate. Antibody perturbation experiments were performed using antiserum against HSF1. Whole-cell extracts were 

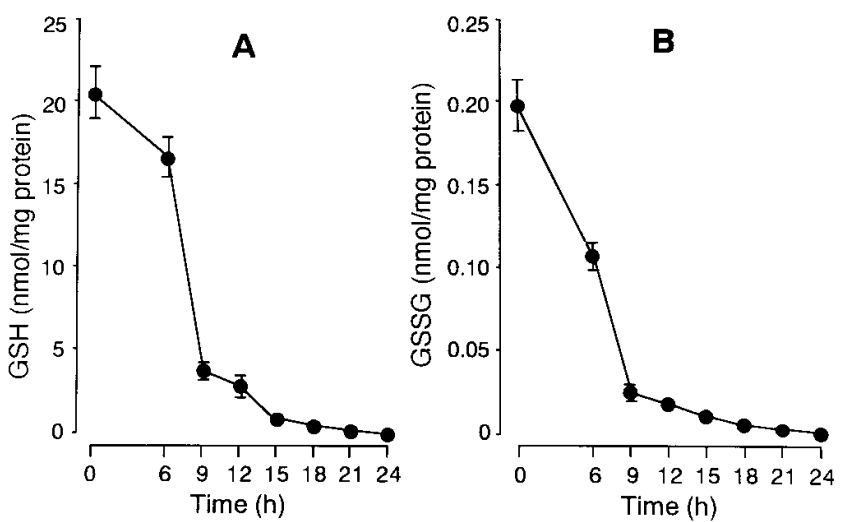

Figure 1. Effect of BSO on glutathione contents of gastric mucosal cells. After treatment of cultured cells with $50 \mu \mathrm{M}$ BSO, acid-soluble thiols were extracted as described in Methods. The fluorodinitrophenyl derivatives of GSH $(A)$ and GSSG $(B)$ were analyzed by the HPLC method of Reed et al. (22). Values are means $\pm \mathrm{SD}, n=4$.

preincubated with $1 \mu \mathrm{l}$ of 100 times diluted antiserum at $4^{\circ} \mathrm{C}$ for 20 min before the binding reaction. Electrophoresis was carried out at $4^{\circ} \mathrm{C}$ for $2-3 \mathrm{~h}$ at $140 \mathrm{~V}$, and then the gels were dried and exposed to Fuji RX-R film.

\section{Results}

Effects of BSO on glutathione contents and cell viability. In our previous study (17), intracellular glutathione was depleted by overnight treatment with BSO at $1 \mathrm{mM}$. After this treatment, both $0.2 \mathrm{mM} \mathrm{H}_{2} \mathrm{O}_{2}$ and $0.2 \mathrm{mM}$ diamide caused cell damage, estimated by the trypan blue exclusion test and increased
Table I. Effects of Heat and Chemicals on the Rate of Protein Synthesis

\begin{tabular}{llc}
\hline & \multicolumn{2}{c}{ Radioactivity $\left(\times 10^{-7} \mathrm{cpm} / \mathrm{mg} \text { protein }\right)^{*}$} \\
\cline { 2 - 3 } \multicolumn{1}{c}{ Treatment } & \multicolumn{1}{c}{ Control cells } & BSO-pretreated cells \\
\hline No treatment & $6.15 \pm 0.13$ & $6.13 \pm 0.10$ \\
Heat $\left(43^{\circ} \mathrm{C}, 10 \mathrm{~min}\right)$ & $5.91 \pm 0.48$ & $5.54 \pm 0.48$ \\
Heat $\left(43^{\circ} \mathrm{C}, 30 \mathrm{~min}\right)$ & $5.31 \pm 0.28^{\ddagger}$ & $5.17 \pm 0.41^{\S}$ \\
Ethanol $(250 \mathrm{mM}, 30 \mathrm{~min})$ & $5.52 \pm 0.43^{\ddagger}$ & $4.98 \pm 0.56^{\S}$ \\
Ethanol $(500 \mathrm{mM}, 30 \mathrm{~min})$ & $4.57 \pm 0.35^{\ddagger}$ & $4.14 \pm 0.24^{\S}$ \\
$\mathrm{H}_{2} \mathrm{O}_{2}(0.2 \mathrm{mM}, 30 \mathrm{~min})$ & $5.65 \pm 0.61$ & $5.34 \pm 0.52^{\S}$ \\
$\mathrm{H}_{2} \mathrm{O}_{2}(0.5 \mathrm{mM}, 30 \mathrm{~min})$ & $5.04 \pm 0.64^{\ddagger}$ & $4.84 \pm 0.30^{\S}$ \\
Diamide $(0.2 \mathrm{mM}, 30 \mathrm{~min})$ & $5.00 \pm 0.21^{\ddagger}$ & $4.26 \pm 0.75^{\S}$ \\
Diamide $(0.5 \mathrm{mM}, 30 \mathrm{~min})$ & $4.26 \pm 0.75^{\ddagger}$ & $3.84 \pm 0.81^{\S}$ \\
& & \\
\hline
\end{tabular}

*After exposure of control and BSO-pretreated cells to heat $\left(43^{\circ} \mathrm{C}\right)$ or the chemicals, they were labeled with L- $\left[{ }^{35} \mathrm{~S}\right]$ methione for $1 \mathrm{~h}$ and then washed three times with PBS. The radioactivity of labeled proteins precipitated with $5 \%(\mathrm{vol} / \mathrm{vol})$ trichloroacetic acid was counted by a liquid scintillation counter. Values are mean $\pm \mathrm{SD}, n=5$. ${ }^{\ddagger}$ Significantly decreased versus unstressed control cells $(P<0.05)$ by Student's $t$ test. ${ }^{\S}$ Significantly decreased versus unstressed BSO-treated cells $(P<0.05)$.

LDH release. In the present study, we treated cells with various concentrations of BSO for $6 \mathrm{~h}$ to determine its minimum effective concentration. BSO at a concentration of $50 \mu \mathrm{M}$ or higher significantly decreased the glutathione content (data not shown). Treatment of cells with $50 \mu \mathrm{M}$ BSO for $18 \mathrm{~h}$ decreased the level of total glutathione to $4.8 \pm 0.6 \%$ (mean \pm SD, $n=8$ ) of the control value (Fig. 1). Cells treated with $50 \mu \mathrm{M}$ BSO for $18 \mathrm{~h}$ are referred to as "glutathione-depleted cells."
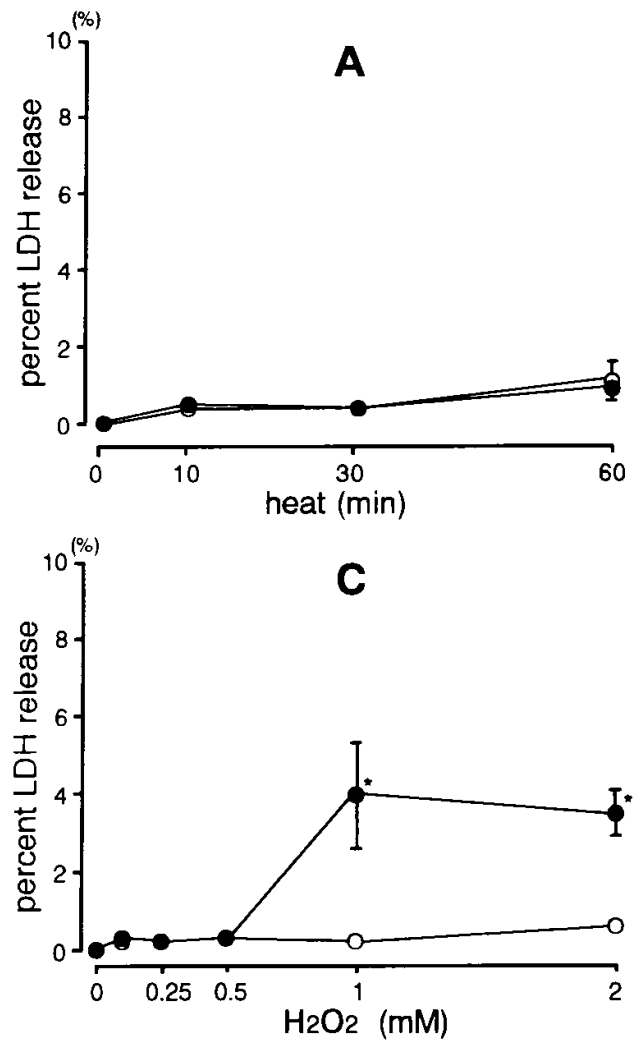
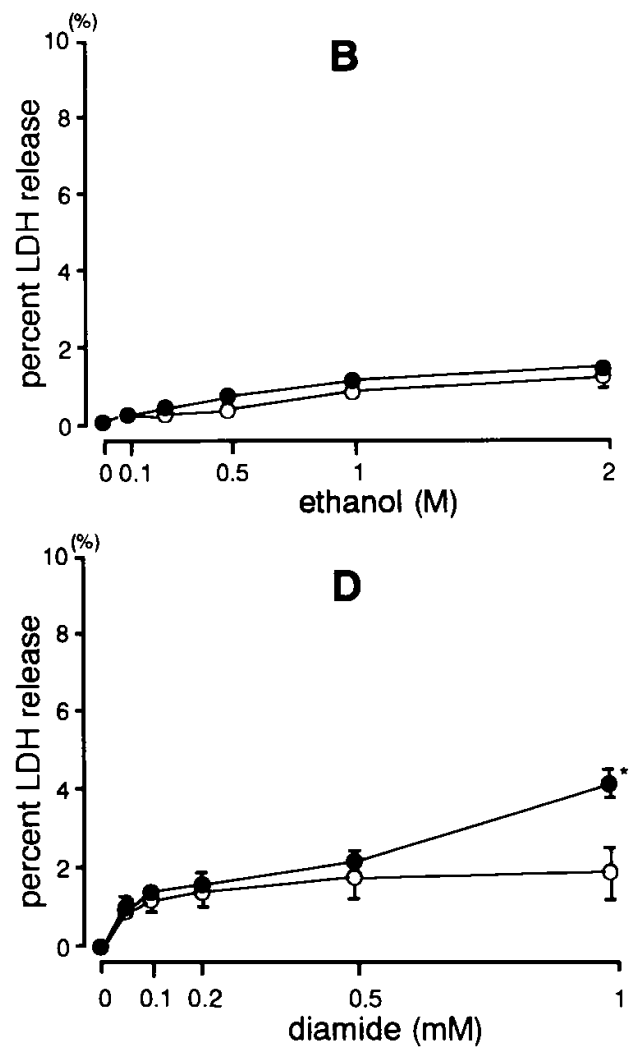

Figure 2. Effect of BSO on stress-induced cell damage. Intracellular glutathione was depleted to $4.8 \pm 0.6 \%$

(mean $\pm \mathrm{SD}, n=8$ ) of the control value by treatment with 50 $\mu \mathrm{M}$ BSO for $18 \mathrm{~h}$. Control $(\bigcirc)$ and BSO-treated cells $(\mathbf{O})$ were exposed either to heat shock at $43^{\circ} \mathrm{C}$ for the indicated times $(A)$, or to various concentrations of ethanol $(B)$, $\mathrm{H}_{2} \mathrm{O}_{2}(C)$, or diamide $(D)$, for $30 \mathrm{~min}$. Percentage of LDH release was measured as described in Methods. Values are means $\pm \mathrm{SD}, n=3$. Student's $t$ test was used to determine the significance of difference between control and BSOtreated cells. Values with an asterisk are significantly different $(P<0.05)$. 
A

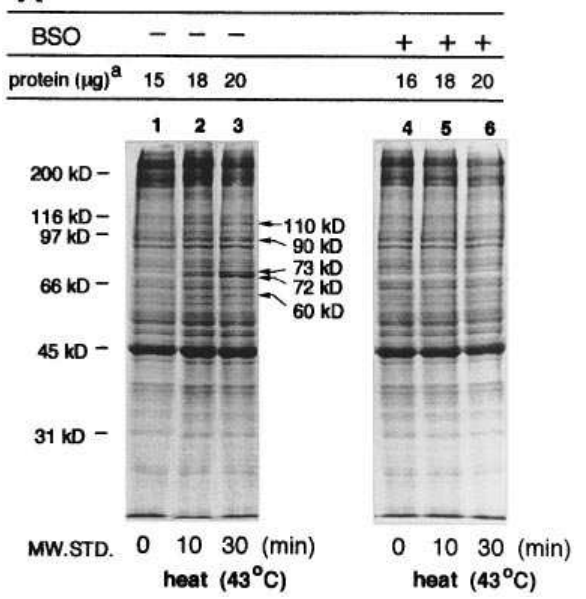

C

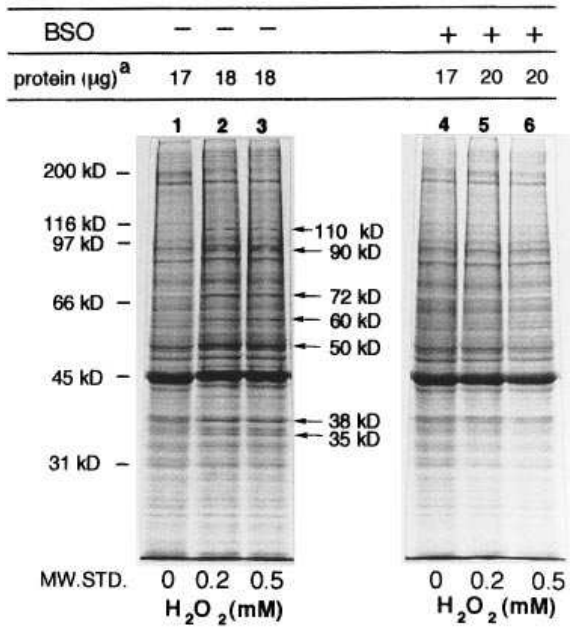

B

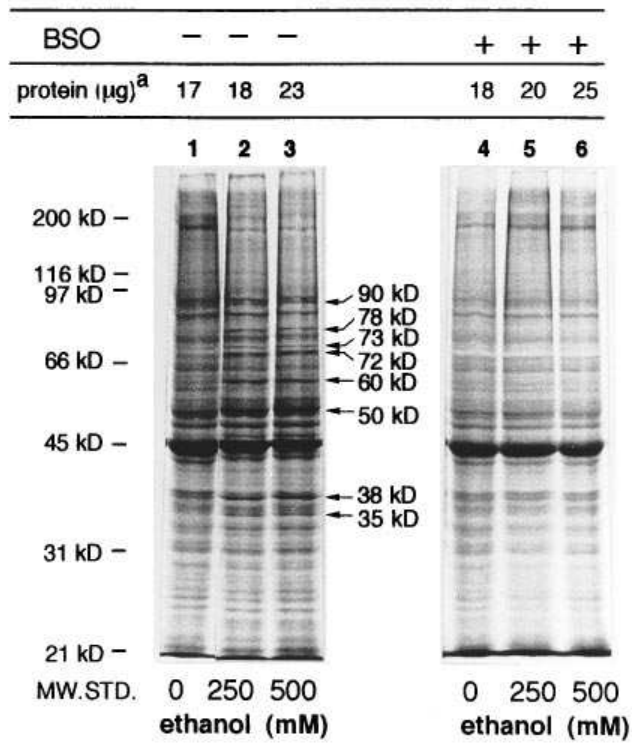

D

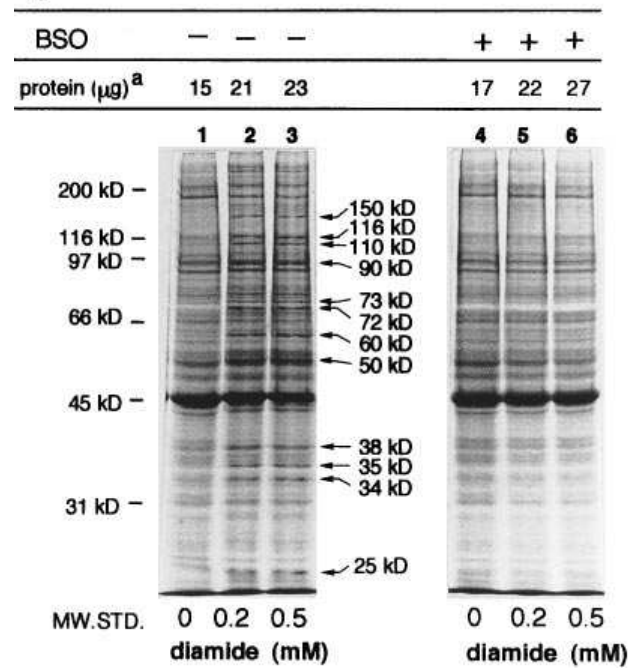

Figure 3. Effect of heat, ethanol, $\mathrm{H}_{2} \mathrm{O}_{2}$, and diamide on protein synthesis in gastric mucosal cells. After exposure to heat stress at $43^{\circ} \mathrm{C}(A)$ for the indicated times, or treatment for $30 \mathrm{~min}$ with ethanol $(B)$, $\mathrm{H}_{2} \mathrm{O}_{2}(C)$, or diamide $(D)$, at the indicated concentrations, control cells and BSO-treated cells were pulse labeled with $\mathrm{L}-\left[{ }^{35} \mathrm{~S}\right] \mathrm{methionine}$ for $1 \mathrm{~h}$ as described in Methods. An equal amount of ${ }^{35} \mathrm{~S}\left(1 \times 10^{5} \mathrm{cpm}\right)$ was separated in $10 \%$ SDSPAGE. The gel was stained with Coomassie brilliant blue R-250, dried, and exposed to Fuji RX film. Molecular masses indicated by arrows were determined with the molecular mass markers shown on the left. Results were similar in five separate experiments. ${ }^{a}$ Each value is the amount of protein $(\mu \mathrm{g})$ applied on each lane.
Glutathione-depleted cells were exposed to heat stress $\left(43^{\circ} \mathrm{C}\right)$, ethanol, $\mathrm{H}_{2} \mathrm{O}_{2}$, or diamide, and cell viability was estimated by the trypan blue exclusion test and by percentage of $\mathrm{LDH}$ release (Fig. 2). Heat stress at $43^{\circ} \mathrm{C}$ for $60 \mathrm{~min}$; or treatment for $30 \mathrm{~min}$ with ethanol at concentrations of up to $2 \mathrm{M}$, with $\mathrm{H}_{2} \mathrm{O}_{2}$ at up to $0.5 \mathrm{mM}$, or with diamide at up to $0.5 \mathrm{mM}$, did not cause any significant difference between LDH release from control and BSO-pretreated cells. Similar results were obtained by the trypan blue exclusion test (data not shown). We also assessed the rate of overall protein synthesis by measuring the $\left[{ }^{35} \mathrm{~S}\right]$ incorporation into TCA-precipitated proteins after metabolic labeling of unstressed and stressed cells with 50 $\mu \mathrm{M} \mathrm{L}-\left[{ }^{35} \mathrm{~S}\right]$ methionine $(16 \mu \mathrm{Ci} / \mathrm{ml})$ for $1 \mathrm{~h}$ (Table I). Pretreatment with BSO did not affect the incorporation in unstressed cells (Table I). Exposure to each metabolic insult as well as heat at $43^{\circ} \mathrm{C}$ decreased the rate of overall protein synthesis in both control and BSO-pretreated cells as listed in Table I. BSO-pretreated cells placed under the stresses showed lower incorporation values than control cells. However, the difference between the incorporation from control and BSO-pre- treated cells did not reach statistical significance, when both types of cells were exposed to the same stressor (Table I).

Effects of various stresses on protein synthesis. Using metabolic pulse-chase labeling and immunoblotting, we found previously that heat stress induced the synthesis of HSP70, HSC73, and HSP90 (7). In the present study, we examined how the stress response occurred in cells placed under stress by treatment with different agents. Both control and glutathionedepleted cells were exposed to heat at $43^{\circ} \mathrm{C}$ (Fig. $3 A$ ) or treated at $37^{\circ} \mathrm{C}$ with ethanol (Fig. $3 \mathrm{~B}$ ), $\mathrm{H}_{2} \mathrm{O}_{2}$ (Fig. $3 C$ ), or diamide (Fig. $3 \mathrm{D}$ ). Immediately after exposure to each stressor, the cells were metabolically labeled with L- $\left[{ }^{35} \mathrm{~S}\right]$ methionine for $60 \mathrm{~min}$. Labeled proteins were separated by SDS-PAGE, and the proteins synthesized were detected by autoradiography. Lanes were loaded on an equal cpm basis. This method reveals the relative rate of synthesis and not the absolute amount of synthesis.

As shown in Fig. $3 \mathrm{~A}$, exposure to heat at $43^{\circ} \mathrm{C}$ for $10 \mathrm{~min}$ was enough to increase the synthesis of $110-, 90-$, and $73-\mathrm{kD}$ proteins, and to induce a $72-\mathrm{kD}$ protein. The $72-\mathrm{kD}$ protein 


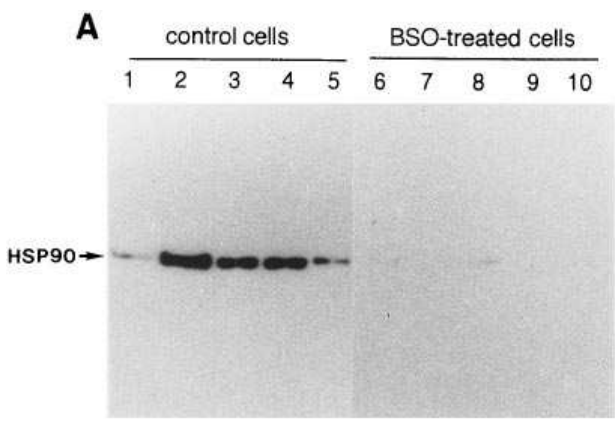

B
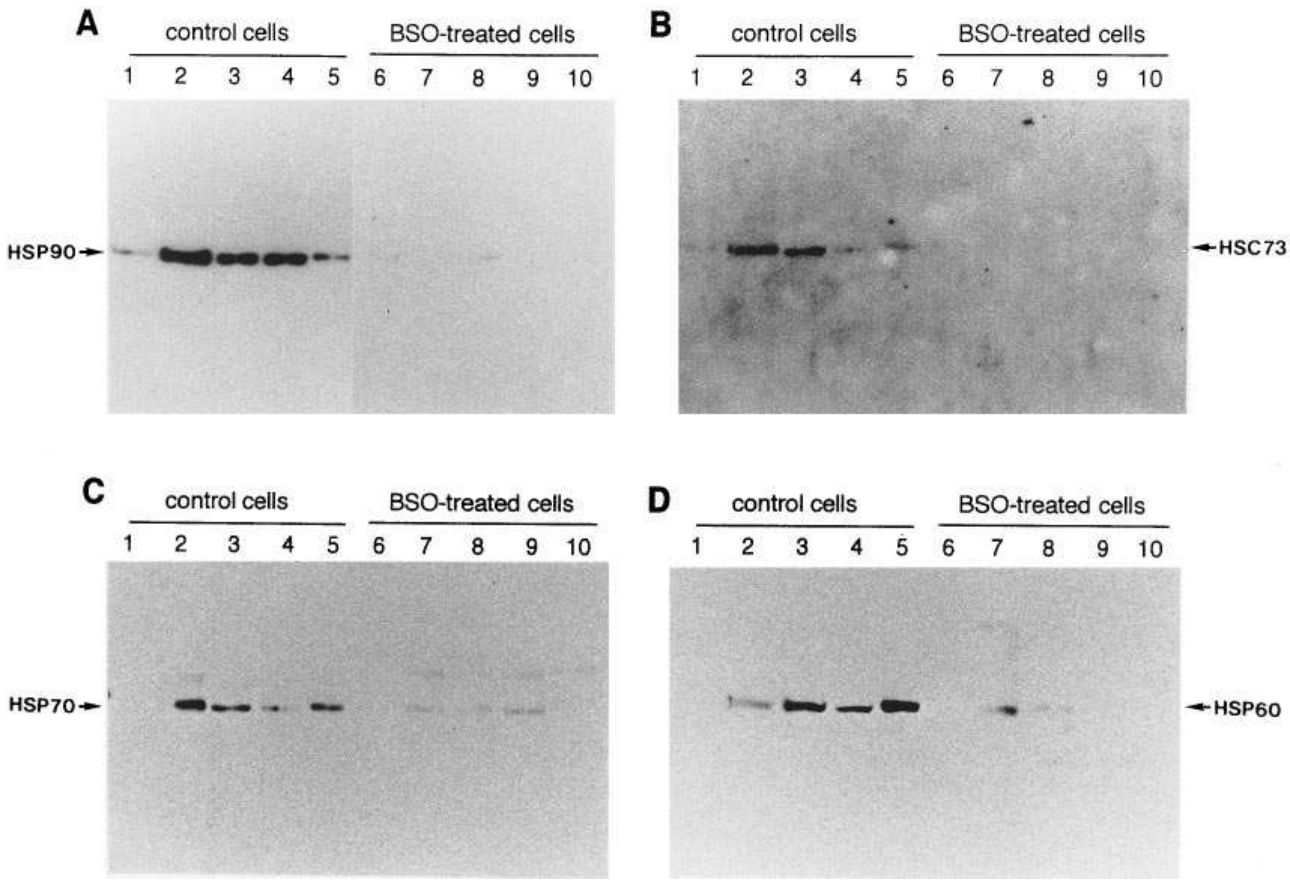

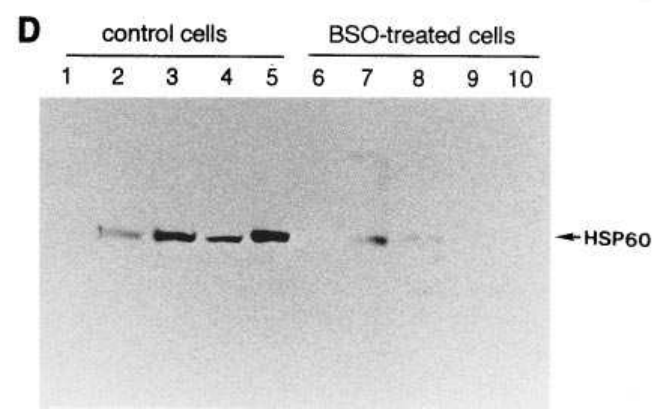

Figure 4. Immunoblot analysis of HSPs in gastric mucosal cells. Control cells (lanes 1-5) and BSO-treated cells (lanes 6-10) were not treated further (lanes 1 and 6 ); or they were exposed to the following: heat at $43^{\circ} \mathrm{C}$ for $30 \mathrm{~min}$ (lanes 2 and 7), $500 \mathrm{mM}$ ethanol for $30 \mathrm{~min}$ (lanes 3 and 8 ), $0.5 \mathrm{mM} \mathrm{H}_{2} \mathrm{O}_{2}$ for $30 \mathrm{~min}$ (lanes 4 and 9 ), or $0.5 \mathrm{mM}$ diamide for $30 \mathrm{~min}$ (lanes 5 and 10). Equal amounts of cell proteins $(30 \mu \mathrm{g}$ protein) were subjected to $10 \%$ SDS-PAGE and transferred to a PVDF membrane. Immunoblot analysis was carried out with antibody against HSP90 $(A), \operatorname{HSC73}(B)$, $\operatorname{HSP70}(C)$, or HSP60 $(D)$ as described in Methods. Results were confirmed in four complete experiments. was prominently induced after exposure to heat for $30 \mathrm{~min}$, when overall protein synthesis was reduced by $15 \%$. In glutathione-depleted cells, the pattern of individual protein synthesis was similar to that of control cells (Fig. $3 \mathrm{~A}$, lane 4 ). Heat stress did not apparently change the pattern, and none of the proteins was induced by heat shock (lanes 5 and 6 ).

When cells were exposed to ethanol, the pattern of induction was different from that in heat-stressed cells. Ethanol prominently induced a $60-\mathrm{kD}$ protein and up-regulated the syntheses of several proteins, including 90-, 78-, 72-, 50-, 38-, $35-\mathrm{kD}$ proteins (Fig. $3 \mathrm{~B}$, lanes 2 and 3 ). In contrast, pretreatment of cells with BSO completely blocked the inductions of these proteins without affecting the relative synthesis of other non-regulated proteins (lanes 4-5).

Induction of HSPs under oxidative stress was examined by treatment of cells with $\mathrm{H}_{2} \mathrm{O}_{2}$ or diamide. The syntheses of a similar group of proteins, which increased their syntheses in response to heat or ethanol, were also up-regulated by $\mathrm{H}_{2} \mathrm{O}_{2}$ (Fig. $3 C$, lanes 2 and 3). Diamide reacts nonenzymatically with sulfhydryl groups to oxidize glutathione, proteins, and other thiols to disulfides. When cells were exposed to this agent, the pattern of protein synthesis was strikingly changed (Fig. $3 \mathrm{D}$, lanes 2 and 3). Treatment with diamide for 30 min induced several other proteins besides the same group of proteins induced by heat, ethanol, or $\mathrm{H}_{2} \mathrm{O}_{2}$. The cells depleted of glutathione with BSO again completely inhibited the inductions of all of these proteins after oxidative challenges (Figs. 3, $C$ and $D$, lanes 5 and 6 ).

We also examined how the glutathione level affected the inductions of these proteins after incubation for $18 \mathrm{~h}$ with various concentrations of BSO. Glutathione depletion did not inhibit the induction of the stress-inducible proteins when its level was not reduced to below $10 \%$ of the control value (data not shown).

Detection of HSPs by Western blotting. The 90-, 73-, 72-, and $60-\mathrm{kD}$ proteins induced by heat and the reagents were most likely HSP90, HSC73, HSP70, and HSP60, respectively. The steady-state levels and inductions of these HSPs were identified by Western blotting with polyclonal antibody against HSP90, HSC73, HSP70, or HSP60. In this case, an equal amount of whole-cell protein ( $30 \mu \mathrm{g}$ protein) was separated by SDS-PAGE. Fig. 4 shows that the extents of accumulation of these HSPs varied with the type of stress. Untreated cells expressed low levels of HSP90 (Fig. $4 A$, lane 1 ), and heat at $43^{\circ} \mathrm{C}$ and the chemicals induced HSP90 similarly (Fig. $4 A$, lanes $2-$ 5). HSC73 was also detected in control cells (Fig. $4 B$, lane 1 ), and its level increased after heat stress or ethanol treatment (lanes 2 and 3). In contrast, unstressed cells had no detectable levels of HSP70 (Fig. $4 C$, lane 1) and HSP60 (Fig. $4 D$, lane 1). Heat stress strikingly induced HSP70 (Fig. $4 C$, lane 2), while ethanol and diamide mainly induced HSP60 (Fig. $4 D$, lanes 3 and 5). These results were similar to those obtained by the labeling method (Fig. 3).

In glutathione-depleted cells, HSC73 was not detected before and even after exposure to heat to each insult (Fig. 4 B). In addition, glutathione depletion substantially suppressed the accumulations of HSP90, HSP70, and HSP60 (lanes 5-10 in Figs. $4, A, C$, and $D$ ), also supporting the results of labeling studies (Fig. 3).

Detection of HSP70 $\mathrm{mRNA}$. Northern blot analysis with human HSP70 cDNA as a probe was carried out to detect the accumulation of HSP70 mRNA after exposure to heat stress or the chemicals (Fig. 5). Low levels of HSP70 mRNA were sometimes detected in unstressed control cells. Each stressor rapidly increased HSP70 mRNA levels within $5 \mathrm{~min}$, and maxima were reached at $30 \mathrm{~min}$. Pretreatment of cells with BSO decreased the steady-state level of GAPDH mRNA, but this level remained constant after exposure to the stresses (Fig. 5). However, the expression of HSP70 mRNA after exposure to heat or the chemicals was completely blocked in glutathionedepleted cells (Fig. 5), suggesting that the inhibition of HSP70 induction might be at the transcriptional level. 
A

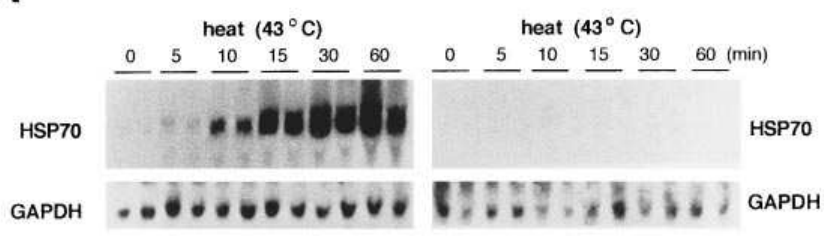

B
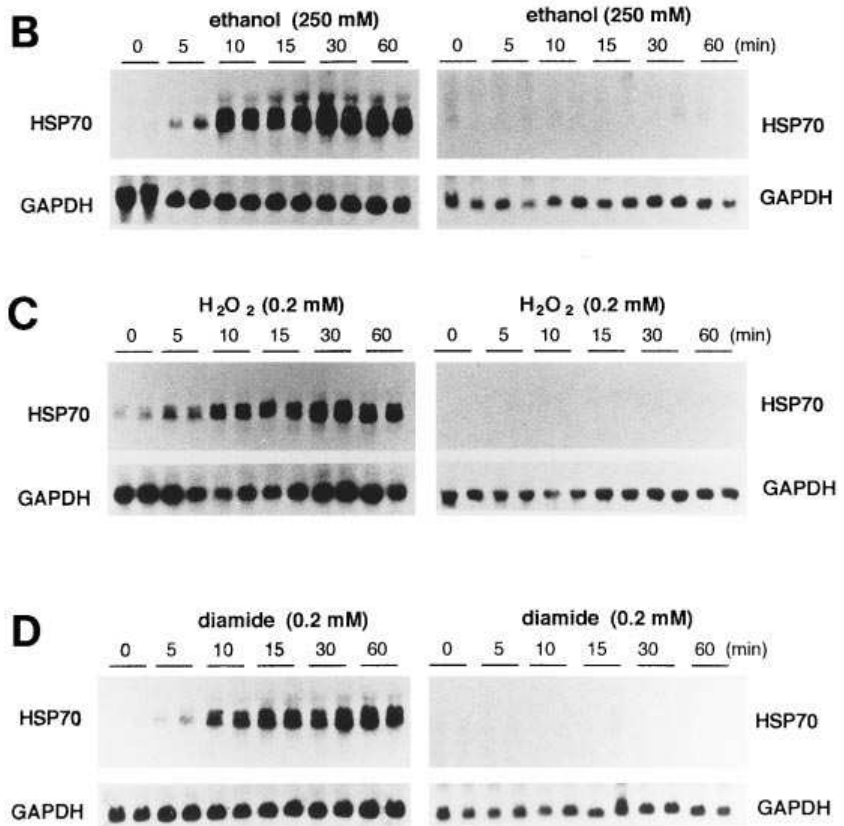

Figure 5. Accumulation of HSP70 mRNA after exposure to stresses. Control cells and BSO-pretreated cells were exposed to heat at $43^{\circ} \mathrm{C}$ $(A), 250 \mathrm{mM}$ ethanol $(B), 0.2 \mathrm{mM} \mathrm{H}_{2} \mathrm{O}_{2}(C)$, or $0.2 \mathrm{mM}$ diamide $(D)$, for the indicated times. Total RNA was extracted as described in Methods. Samples of $15 \mu \mathrm{g}$ of RNA were separated in $1 \%$ agarose gel and transferred to nylon membrane filters. The filters were hybridized with the cDNA probe for human HSP70 or GAPDH as described in Methods. Bound probes were detected by autoradiography. Results were confirmed in four separate experiments.

Identification of HSF-HSE complex in control and BSOpretreated cells. Activation of HSF was examined by gel mobility shift assay using a synthetic double-stranded oligonucleotide corresponding to the two overlapping HSEs located between positions -107 and -83 in the human HSP70 promoter (23). Gastric mucosal cells maintained at $37^{\circ} \mathrm{C}$ contained an HSE binding activity, indicated as "ns" in Fig. $6 A$, which did not compete for excess unlabeled HSE oligonucleotide (Fig. $6 \mathrm{~A}$, lanes 18 and 19). Exposure to heat at $43^{\circ} \mathrm{C}$ produced another protein-DNA complex within $5 \mathrm{~min}$, which migrated slowly (indicated by "h" in Fig. $6 A$, lanes 2-4). This band competed for excess unlabeled self oligonucleotide (Fig. $6 \mathrm{~A}$, lanes 18 and 19), but not for non-self oligonucleotide (Fig. $6 \mathrm{~A}$, lanes 20 and 21 ). Gel mobility shift assay demonstrates that ethanol, $\mathrm{H}_{2} \mathrm{O}_{2}$, and diamide also induced this HSE-binding activity (Fig. $6 A$, lanes 5-13). The relationship of the activated HSE-binding proteins was examined further in supershift experiments with antiserum against HSF1. The antiserum supershifted the band (h) and produced a more slowly migrating band (indicated by an arrow) in the extracts of control cells exposed to heat (Fig. $6 \mathrm{~A}$, lane 14), $250 \mathrm{mM}$ ethanol (lane 15),
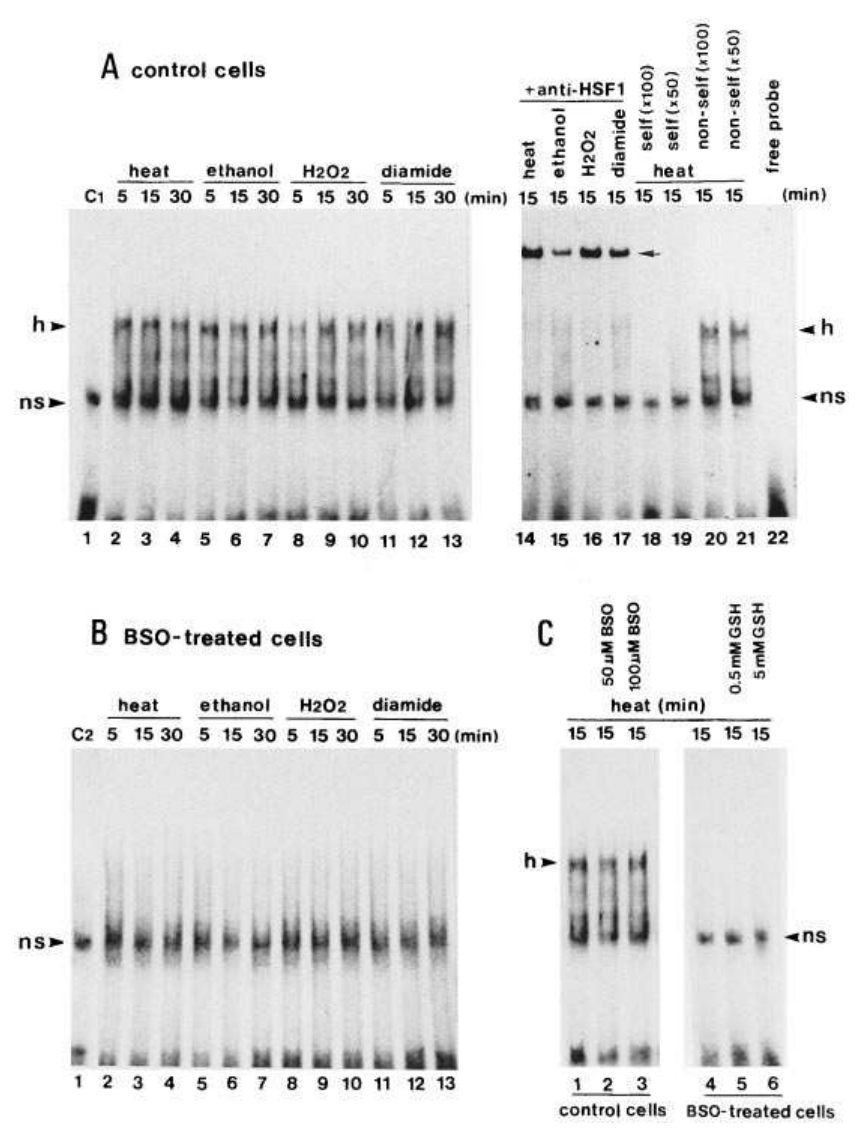

Figure 6. Detection of HSF-binding activity after heat shock. (A) After control cells were exposed to heat stress at $43^{\circ} \mathrm{C}$ or treated with $250 \mathrm{mM}$ ethanol, $0.2 \mathrm{mM} \mathrm{H}_{2} \mathrm{O}_{2}$, or $0.2 \mathrm{mM}$ diamide, whole cell proteins were extracted as described in Methods. Gel mobility shift assay was performed with a $\left.{ }^{32} \mathrm{P}\right] \mathrm{HSE}$ oligonucleotide as described in Methods. Lanes 14-17 show supershift experiments with antiserum against HSF1. Lanes 18 and 19, marked self, contained 100- and 50-fold molar excess of unlabeled HSE oligonucleotide, respectively. Lanes 20 and 21 contained 100- and 50-fold molar excess of unlabeled AP-1 oligonucleotide, respectively. Lane 22 lacked cell proteins. (B) Whole-cell extracts from BSO-treated cells exposed to heat at $43^{\circ} \mathrm{C}$, $250 \mathrm{mM}$ ethanol, $0.2 \mathrm{mM} \mathrm{H}_{2} \mathrm{O}_{2}$, or $0.2 \mathrm{mM}$ diamide were subjected to gel mobility shift assay as described in Methods. (C) Whole-cell extracts from control cells exposed to heat for 15 min were untreated (lane 1) or treated with 50 (lane 2) or $100 \mu \mathrm{M}$ BSO (lane 3) during the binding reaction. Lanes 5 and 6 contained $0.5 \mathrm{mM}$ and $5 \mathrm{mM}$ GSH in the binding reaction mixture, respectively. Interaction shown by $h$ was specific HSE-binding activity. $n s$, nonspecific interaction. Results were similar in six separate experiments.

$0.2 \mathrm{mM} \mathrm{H}_{2} \mathrm{O}_{2}$ (lane 16), and $0.2 \mathrm{mM}$ diamide (lane 17), suggesting that the increase in transcription and accumulation of HSP70 transcripts by heat, ethanol, $\mathrm{H}_{2} \mathrm{O}_{2}$, and diamide were mediated through activation of HSF1.

When whole-cell extracts from BSO-pretreated cells were incubated with the HSE oligonucleotide, a single nonspecific binding, indicated by "ns," was observed (Fig. $6 \mathrm{~B}$, lane 1). Heat stress and the chemicals did not produce additional protein-HSE complex corresponding to the HSF1-HSE complex (Fig. $6 \mathrm{~B}$, lanes 2-13). This inhibition by pretreatment with $\mathrm{BSO}$ was not due to the direct action of BSO, since the inhibition of HSP induction did not occur after treatment with 50 $\mu \mathrm{M}$ BSO for shorter periods, when the glutathione level was 

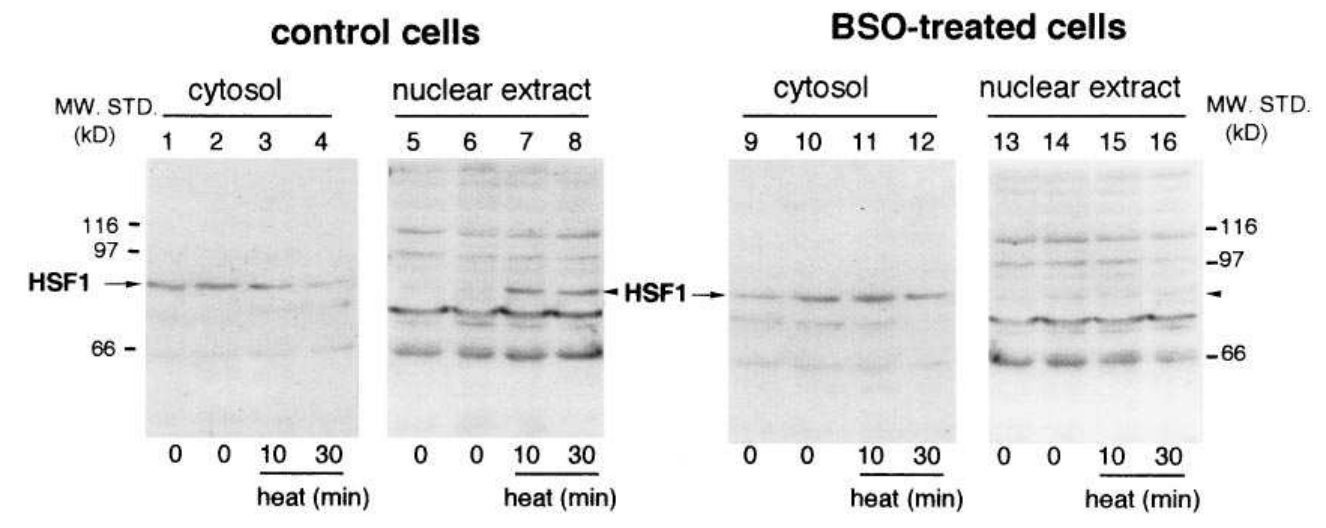

Figure 7. Immunoblot analysis of HSF1 in gastric mucosal cells. Before and after exposure of control and BSOtreated cells to heat $43^{\circ} \mathrm{C}$ for the indicated times, cytosol and nuclear fractions were prepared and subjected to $10 \%$ SDS-PAGE as described in Methods. The separated proteins were transferred to a PVDF membrane. Immunoblot analysis was carried out with antiserum against HSF1 as described in Methods. Similar results were obtained in three separate experiments. not reduced to below $10 \%$ of the control level. Furthermore, an addition of 50 or $100 \mu \mathrm{M}$ BSO to whole-cell extract from heat-stressed control cells did not block the HSE binding (Fig. $6 C$, lanes 2 and 3). We also examined whether replacement of GSH to whole-cells extracts from glutathione-depleted cells could restore the HSE-binding activity. Lanes 5 and 6 in Fig. 6 $C$ show that the supplementation of GSH did not recover the binding activity in the whole-cell extracts from glutathionedepleted cells exposed to heat stress for $15 \mathrm{~min}$.

Detection of HSF1 in gastric mucosal cells. The results from gel mobility shift assay suggested that glutathione-depleted cells might not contain enough HSF1 protein, otherwise, they might impair the activation processes of HSF1 after exposure to heat or the chemicals. Mammalian cells have at least three HSF genes encoding HSF1, HSF2, and HSF3 (26-29). HSF1 is the primary activator of heat shock gene transcription in response to stress $(28,30,31)$. According to the results from gel mobility shift assay, Western blot analysis with antiserum against HSF1 was performed to determine the steady-state level and the distribution of HSF1 in cytosol and nuclear extracts (Fig. 7). Before heat stress, HSF1 was mainly detected in the cytosol from control (lanes 1 and 2) and BSO-treated cells (lanes 9 and 10), and the steady-state level of HSF1 was not affected by pretreatment with BSO. Heat stress promoted the translocation of HSF1 from cytosol (lanes 3 and 4) to nuclear fractions (lanes 5 and 6 ) in control cells, but pretreatment with BSO inhibited this nuclear translocation at 10 and $30 \mathrm{~min}$ of heat stress (lanes 15 and 16).

\section{Discussion}

Homeostasis of cellular function is a consequence of a genetic program that endows individual cells with the ability to respond to environmental stress. A typical stress response was observed in primary cultures of gastric mucous epithelial cells. These cells are believed to serve a primary protective role by providing a mucous coat in the stomach and are frequently exposed to physiological and chemical stressors derived from ingested food. Pre-exposure of cultured gastric mucosal cells to heat shock and induction of HSPs protect these cells from subsequent injury by ethanol (7), and this response may participate in adaptive cytoprotection of gastric tissue in vivo.

HSPs were induced in cultured gastric mucosal cells not only by heat shock but also by exposure to other metabolic insults (ethanol, $\mathrm{H}_{2} \mathrm{O}_{2}$, and diamide). Metabolic labeling studies and immunoblot analyses clearly showed that heat stress at $43^{\circ} \mathrm{C}$ and these chemicals up-regulated the syntheses of the stress-inducible HSP90, HSP70, HSP60, and a constitutively expressed HSC73, although the pattern of their induction varied depending on the type of stress.

The present experiments were designed to determine the role of glutathione in mediating the initial biochemical events leading to the transcriptional activation of HSP genes. For this purpose, the intracellular glutathione pool was depleted with BSO before induction of HSPs. The inductions of the proteins by various types of stress were almost completely inhibited, when intracellular glutathione was depleted to $<10 \%$ of the control level. Saunders et al. also reported that $\mathrm{CHO}$ cells depleted of glutathione did not induce HSPs (32), but they showed, in a subsequent study, that glutathione depletion oppositely enhanced HSP70 induction in Hep G2 cells (33). Our observations might be limited to primary cultures of gastric mucosal cells, but both metabolic labeling and Western blot analyses clearly demonstrated that the stress response did not occur in gastric mucosal cells depleted of glutathione. This inhibition was not due to cell damage. We carefully examined the effects of the period of exposure to heat shock and the concentrations of chemicals at which the cells did not significantly release $\mathrm{LDH}$.

Northern blot analysis with the cDNA probe for human HSP70 demonstrated that accumulation of HSP70 mRNA did not occur in glutathione-depleted cells exposed to heat, ethanol, $\mathrm{H}_{2} \mathrm{O}_{2}$, or diamide. The heat shock response in mammalian cells is mediated by activation of pre-existing transcription factors (HSFs) $(8,9)$. Recently, a family of HSFs has been identified in mammalian cells, and the complexity of transcriptional regulation of heat shock genes has been suggested to be due to the differential activations of distinct HSF family members (26-29). HSF1 was identified as the mediator of stress-induced transcription of heat shock genes $(28,30,31)$. Activation of heat shock gene transcription by HSF1 in response to stress conditions is associated with its oligomerization, nuclear localization, and acquisition of binding activity to $\operatorname{HSE}(30,34,35)$, which consists of a contiguous array of alternately oriented pentanucleotide 5'-nGAAn-3' units (36-38).

Gel mobility shift assay showed that not only heat shock but also each metabolic insult activated HSF1. We further examined the mechanism by which glutathione depletion inhibited the activation of HSF1. Western blot analysis with antibody against HSF1 showed that glutathione depletion did not 
reduce the amount of HSF1 protein in the cytosol from unstressed cells, but it blocked the nuclear translocation of HSF1 after heat shock. Gel mobility shift assay showed that none of the stressors activated HSF1 in glutathione-depleted cells. Although glutathione-depleted cells contained similar levels of immunoreactive HSF1 protein, multiple activation processes besides nuclear translocation may be impaired by depletion of glutathione, since we preferentially used whole-cell extracts to determine the HSE-binding activity instead of nuclear extracts. The reagents or conditions that induced the heat shock response cause oxidative stress and depletion of glutathione reduces antioxidant defense. Replacing GSH in whole-cell extracts from BSO-pretreated and heat-stressed cells did not restore the HSF1 activity. We should be concerned about the possibility that HSF1 might be irreversibly inactivated, i.e., autooxidation of HSF1. Thus, intracellular glutathione plays an important role in defense against oxidative stress not only as an antioxidant but also as a modulator of the heat shock response. Alternatively, Huang et al. reported that thiol reducing agents, such as DTT or 2-mercaptoethanol, inhibited the heat-initiated activation processes of HSF, i.e., its trimerization, phosphorylation, and nuclear translocation (39). The report and our findings support, but do not prove, the concept that a glutathione redox buffer system may participate in HSP gene expression by functioning as an environmental sensor and a signal transducer in the stress response.

Ethanol and $\mathrm{H}_{2} \mathrm{O}_{2}$ induced several other proteins with different molecular masses from those of known HSPs, as well as major HSPs examined. Furthermore, the thiol-oxidizing agent diamide induced a larger number of proteins than the other stressors did, suggesting that oxidation of intracellular thiols may trigger the induction of certain stress-related proteins. Glutathione depletion completely inhibited the inductions of all of the proteins. We also found that glutathione depletion inhibited $\mathrm{H}_{2} \mathrm{O}_{2}$ - or diamide-initiated activation of AP-1 and Jun-2 in cultured gastric mucosal cells (unpublished observations). It has been reported that modulation of the redox state and the function of a key regulatory protein(s) by glutathione depletion abolishes the activations of transcription factors such as AP-1, Egr-1, and NF-кB (40, 41). Several transcription factors contain redox-sensitive cysteine residues, whose oxidation states affect DNA binding activity in vitro. These factors include AP-1 (42), NF-кB/Rel (43), Myb (44), NF1 (45), and Egr-1 (40). An important role of GSSG in the activations of these redox-sensitive factors has been suggested (46), but there is no evidence for the direct interaction of glutathione redox potential with any transcription factor in the redox signal cascade. Recently, reversible oxidation of cysteine sulfhydryl residues to sulfenic acid residues (-SOH) has been proposed to be a biochemical mechanism of redox regulation of DNAbinding activity $(47,48)$, and a highly basic environment surrounding the oxidation-sensitive cysteine residues is necessary to stabilize sulfenic acid residues (48). However, another biochemical modification of reversible disulfide formation with glutathione, a process called S-thiolation/dethiolation, may also account for the redox regulation of the specific cysteine residues, since the basic environment favors negatively charged glutathione, and sulfenic acid forms disulfides with low-molecular-weight thiols (48). This modification may preserve the biological activity of the cysteine sulfhydryl residues, which otherwise may undergo irreversible oxidation to sulfinic and sufonic acids. We have shown that oxidative stress initiates
S-thiolation of specific proteins in various types of cells (4951), including cultured gastric cells (17). We have also found that diamide initiates more profound S-thiolation of nuclear proteins than cytosolic proteins (unpublished observation).

The present study does not completely reveal the biochemical events leading to inhibition of activation of HSF1 in glutathione-depleted cells. However, our results suggest that intracellular glutathione in gastric mucosal cells may be involved in early and important steps in the acquisition of an adaptive response to irritants, and they support the concept that endogenous glutathione plays an important role in gastric mucosal cytoprotection.

\section{Acknowledgments}

We are grateful to Dr. Hideaki Itoh, Akita University, for preparation of anti-HSP antibodies. We also thank Dr. Akira Nakai and Dr. Kazuhiro Nagata, Kyoto University, for providing us with antiserum against HSF1.

This work was supported by a Grant-in-Aid for Scientific Research from the Japanese Ministry of Education, Science and Culture (to K. Rokutan).

\section{References}

1. Robert, A., J.E. Nezamis, C. Lancaster, J.P. Davis, S.O. Field, A.J. Hanchar. 1983. Mild irritants prevent gastric necrosis through "adaptive cytoprotection" mediated by prostaglandin. Am. J. Physiol. 245 (Gastrointest. Liver Physiol. 8):G113-G121.

2. Tepperman, B.L., and E.D. Jacbson. 1994. Circulatory factors in gastric mucosal defense and repair. In Physiology of the Gastrointestinal Tract. L.R. Johnson, D.H. Alpers, J. Christensen, E.D. Jacobson, and J.H. Walsh, editors, Raven Press, New York. 1331-1351.

3. Ames, B.N. 1983. Dietary carcinogens and anticarcinogens. Science (Wash. DC). 221:1256-1264.

4. Carlson, J., Y. Iwami, and T. Yamada. 1983. Hydrogen peroxide excretion by oral streptococci and effect of lactoperoxidase-thiocyanate-hydrogen peroxide. 1983. Infect. Immunol. 40:70-80.

5. Cross, C.E.B., B. Halliwel, and A. Allen. 1984. Antioxidant protection: a function of tracheobronchial and gastrointestinal mucus. Lancet. 1:1328-1330.

6. Nakayama, T., M. Kodama, and C. Nagata. 1984. Generation of hydrogen peroxide and superoxide anion radical from cigarette smoke. Gann. 75:95-98.

7. Nakamura, K., K. Rokutan, N. Marui, A. Aoike, and K. Kawai. 1991. Induction of heat shock proteins and their implication in protection against ethanol-induced damage in cultured guinea pig gastric mucosal cells. Gastroenterology. 101:161-166.

8. Lis, J.T., and C. Wu. 1993. Protein traffic on the heat shock promoter: parking, stalling, and trucking along. Cell. 74:1-4.

9. Morimoto, R.I. 1993. Cells in stress: transcriptional activation of heat shock genes. Science (Wash. DC). 259:1409-1410.

10. Meister, A., and M.E. Anderson. 1983. Glutathione. Ann. Rev. Biochem. 52:711-760.

11. Meister, A. 1994. Glutathione-ascorbic acid antioxidant system in animals. J. Biol. Chem. 269:9397-9400.

12. Szabo, S., J.S. Trier, and P.W. Frankel. 1981. Sulfhydryl compound may mediate gastric cytoprotection. Science (Wash. DC). 214:200-202.

13. Robert, A., D. Eberle, and N. Kaplowitz. 1984. Role of glutathione in gastric mucosal cytoprotection. Am. J. Physiol. 247 (Gastrointest. Liver Physiol. 10): G296-304.

14. Victor, B.E., K.L. Schmidt, G.S. Smith, and T.A. Miller. 1991. Protection against ethanol injury in the canine stomach: role of mucosal glutathione. Am. J. Physiol. 261 (Gastrointest. Liver Physiol. 24):G966-G973.

15. Hiraishi, H., A. Terano, S. Ota, H. Mutou, T. Sugimoto, M. Razandi, and K.J. Ivey. 1991. Antioxidant defenses of cultured gastric cells: role of GSH redox cycle and endogenous catalase. Am. J. Physiol. 261 (Gastrointest. Liver Physiol. 24):G921-G928.

16. Mutou, H., S. Ota, H. Hiraishi, K.J. Ivey, A. Terano, and T. Sugimoto. 1991. Reduced glutathione protects cultured gastric mucosal cells from suckling rats against acid. Am. J. Physiol. 261 (Gastrointest. Liver Physiol. 24):G65-G70.

17. Rokutan, K., R.B. Johnston, Jr., and K. Kawai. 1994. Oxidative stress induces S-thiolation of specific proteins in cultured gastric mucosal cells. Am. J. Physiol. 266 (Gastrointest. Liver Physiol. 29):G247-G254.

18. Mitchell, J.B., A. Russo, T.J. Kinsella, and E. Glatstein. 1983. Glutathione elevation during thermotolerance induction and thermosensitization by glutathione depletion. Cancer Res. 43:987-991. 
19. Itoh, H., I. Toyoshima, H. Mizunuma, R. Kobayashi, and Y. Tashima. 1990. Three-step purification method and characterization of the bovine brain 90-kDa heat shock protein. Arch. Biochem. Biophys. 282:290-296.

20. Wakui, H., H. Itoh, Y. Tashima, R. Kobayashi, Y. Nakamoto, and A.B. Miura. 1991. Specific antibodies against the stress-inducible 72-kDa protein, a member of the heat-shock protein hsp70, in healthy human subjects. Int. J. Biochem. 23:975-978.

21. Otaka, M., H. Itoh, T. Kuwabara, A. Zeniya, S. Fujimori, Y. Tashima, and O. Masamune. 1993. Induction of a $60-\mathrm{kDa}$ heat shock protein in rat pancreas by water-immersion stress. Int. J. Biochem. 25:1769-1773.

22. Reed, D.J., J.R. Babson, P.W. Beatty, A.E. Brodie, W.W. Ellis, and D.W. Potter. 1980. High-performance liquid chromatography analysis of nanomole levels of glutathione, glutathione disulfide, and related thiols and disulfides. Anal. Biochem. 106:55-62.

23. Mosser, D.D., N.G. Theodorakis, and R.I. Morimoto. 1988. Coordinate changes in heat shock element-binding activity and HSP70 gene transcription rates in human cells. Mol. Cell. Biol. 8:4736-4744.

24. Schreiber, E., P. Matthias, M.M. Müller, and W. Schaffner. 1989. Rapid detection of octamer binding proteins with 'mini-extracts', prepared from a small number of cells. Nucleic Acids Res. 17:6419.

25. Chomczynski, P., and N. Sacchi. 1987. Single-step method of RNA isolation by acid guanidinium thiocyanate-phenol-chloroform extraction. Anal. Biochem. 162:156-159.

26. Rabindran, S.K., G. Giorgi, J. Clos, and C. Wu. 1991. Molecular cloning and expression of a human heat shock factor, HSF1. Proc. Natl. Acad. Sci. USA. 88:6906-6910.

27. Sarge, K.D., V. Zimarino, K. Holm, C. Wu, and R.I. Morimoto. 1991. Cloning characterization of two mouse heat shock factors with distinct inducible and constitutive DNA-binding ability. Genes Dev. 5:1902-1911.

28. Schuetz, T.J., G.J. Gallo, L. Sheldon, P. Tempst, and R.E. Kingston. 1991. Isolation of a cDNA for HSF2: evidence for two heat shock factor genes in humans. Proc. Natl. Acad. Sci. USA. 88:6911-6915.

29. Nakai, A., and R.I. Morimoto. 1993. Characterization of a novel chicken heat shock transcription factor, heat shock factor 3, suggests a new regulatory pathway. Mol. Cell. Biol. 13:1983-1997.

30. Sarge, K.D., S.P. Murphy, and R.I. Morimoto. 1993. Activation of heat shock gene transcription by heat shock factor 1 involves oligomerization, acquisition of DNA-binding activity, and nuclear localization and can occur in the absence of stress. Mol. Cell. Biol. 13:1392-1407.

31. Sistonen, L., K.D. Sarge, and R.I. Morimoto. 1994. Human heat shock factors 1 and 2 are differentially activated and can synergistically induce hsp70 gene transcription. Mol. Cell. Biol. 14:2087-2099.

32. Saunders, E.L., M.D. Maines, M.J. Meredith, and M.L. Freeman. 1991. Enhancement of heme oxygenase-1 synthesis by glutathione depletion in Chinese hamster ovary cells. Arch. Biochem. Biophys. 288:368-373.

33. Freeman, M.L., E. Sierra-River, G.J. Voorhees, D.R. Eisert, and M.J. Meredith. 1993. Synthesis of hsp-70 is enhanced in glutathione-depleted Hep G2 cells. Radiat. Res. 135:387-393.

34. Baler, R., G. Dahl, and R. Voellmy. 1993. Activation of human heat shock genes is accompanied by oligomerization, modification, and rapid translocation of heat shock transcription factor HSF1. Mol. Cell. Biol. 13:2486-2496.
35. Rabindran, S.K., R.I. Haroun, J. Clos, J. Wisniewski, and C. Wu. 1993. Regulation of heat shock factor trimer formation: role of a conserved leucine zipper. Science (Wash. DC). 259:230-234.

36. Amin, J., J. Ananthan, and R. Voellmy. 1988. Key features of heat shock regulatory elements. Mol. Cell. Biol. 8:3761-3769.

37. Perisic, O., H. Xiao, and H.C.M. Nelson. 1989. Stable binding of Drosophila heat shock factor to head-to-head and tail-to-tail repeats of a conserved 5 bp recognition unit. Cell. 59:797-806.

38. Xiao, H., and J.T. Lis. 1988. Germline transformation used to define key features of the heat shock response element. Science (Wash. DC). 239:11391142 .

39. Huang, L.E., H. Zhang, S.W. Bae, and A.Y.-C. Liu. 1994. Thiol reducing reagents inhibit the heat shock response. J. Biol. Chem. 269:30718-30725.

40. Esposito, F., V. Agosti, G. Morrone, F. Morra, C. Cuomo, T. Russo, S Venuta, and F. Cimino. 1994. Inhibition of the differentiation of human myeloid cell lines by redox changes induced through glutathione depletion. Biochem. J. 301:649-653.

41. Galter, D., S. Mihm, and W. Dröge. 1994. Distinct effects of glutathione disulfide on the transcription factors $\kappa \mathrm{B}$ and the activator protein-1. Eur. J. Biochem. 221:639-648.

42. Abate, C., L. Patel, F.J. Rauscher III, and T. Curran. 1990. Redox regulation of Fos and Jun DNA-binding activity in vitro. Science (Wash. DC). 249: $1157-1161$.

43. Kumar, S., A.B. Rabson, and C. Celinas. 1992. The RxxRxRxxC motif conserved in all $\mathrm{Rel} / \mathrm{\kappa} \mathrm{B}$ proteins is essential for the DNA-binding activity and redox regulation of the v-Rel oncoprotein. Mol. Cell. Biol. 12:3094-3106.

44. Guehmann, S., G. Vorbrueggen, F. Kalkbrenner, and K. Moelling. 1992 Reduction of a conserved Cys is essential for Myb DNA-binding. Nucleic Acids Res. 20:2279-2286.

45. Novak, A., N. Goyal, and R.M. Gronostajski. 1992. Four conserved cystein residues are required for the DNA binding activity of nuclear factor I. $J$ Biol. Chem. 267:12986-12990.

46. Dröge, W., K. Schulze-Osthoff, S. Mihm, D. Galter, H. Schenk, H.-P. Eck, S. Roth, and H. Gmünder. 1994. Functions of glutathione and glutathione disulfide in immunology and immunopathology. FASEB J. 8:1131-1138.

47. Storz, G., L.A. Tartaglia, and B.N. Ames. 1990. Transcriptional regulator of oxidative stress-inducible genes: direct activation by oxidation. Science (Wash. DC). 248:189-194.

48. Claiborne, A., H. Miller, D. Parsonage, and R.P. Moss. 1993. Proteinsulfenic acid stabilization and function in enzyme catalysis and gene regulation. FASEB J. 7:1483-1490.

49. Rokutan, K., J.A. Thomas, and H. Sies. 1989. Specific S-thiolation of a 30-kDa cytosolic protein from rat liver under oxidative stress. Eur. J. Biochem. 179:233-239.

50. Rokutan, K., J.A. Thomas, and R.B. Johnston, Jr. 1991. Phagocytosis and stimulation of the respiratory burst by phorbol diester initiate S-thiolation of specific proteins in macrophages. J. Immunol. 147:260-264.

51. Chai, Y.-C., S.S. Ashraf, K. Rokutan, R.B. Johnston, Jr., and J.A. Thomas. 1994. S-Thiolation of individual human neutrophil proteins including actin by stimulation of the respiratory burst: evidence against a role for glutathione disulfide. Arch. Biochem. Biophys. 310:273-281. 